\title{
Screening Lettuce Germplasm for New Sources of Resistance to Corky Root
}

\author{
Beiquan Mou' ${ }^{1}$ and Carolee Bull ${ }^{2}$ \\ U.S. Department of Agriculture, Agricultural Research Service, 1636 East Alisal Street, Salinas, \\ CA 93905
}

ADDITIONAL INDEX WORDS. Sphingomonas suberifaciens, Rhizomonas suberifaciens, disease resistance, molecular marker,
Lactuca sativa, Lactuca serriola, Lactuca saligna, Lactuca virosa

\begin{abstract}
Corky root is a major disease of lettuce (Lactuca sativa L.) observed in many production areas of the world. The pathogen Sphingomonas suberifaciens (van Bruggen et al.) Yabuuchi et al. varies with regard to virulence, and several strains have been isolated that can cause disease symptoms even on cultivars that have the only known resistance gene, cor. It is desirable to find new sources of resistance to diversify the genetic basis of the resistance and to confer resistance against isolates that are not adequately controlled by cor. More than 1000 plant introduction lines and cultivars were screened in assays conducted in the greenhouse, growth chamber, and field. Three $L$. serriola $\mathrm{L}$. lines (PI 491239, PI 491096, and PI 491110) and a L. virosa L. line (PI 273597c) were highly resistant to corky root in all tests. Disease severity ratings in the field were correlated with the ratings in the greenhouse $(r=0.722)$ and in the growth chamber $(r=0.650)$. Significant genotype $\times$ environment interactions were observed for corky root severity. None of the four resistant lines had the two molecular markers closely linked to the cor allele. The information on disease resistance for these genotypes will be useful in future breeding work.
\end{abstract}

Corky root disease has been observed in lettuce-producing areas in North America, Western Europe, Australia, and New Zealand, and may affect all types of lettuce. Infected plants develop yellow to brown lesions on the roots and the lesions later become longitudinal corky ridges. In severely infested fields in California and Florida, yield losses from reduced head size can reach $30 \%$ to $70 \%$ (van Bruggen, 1997). The pathogen most commonly isolated from diseased roots is a bacterium at first named Rhizomonas suberifaciens van Bruggen et al. (van Bruggen et al., 1990b), although several other species have been isolated (van Bruggen, 1997). Sphingomonas suberifaciens is the currently accepted name for this pathogen, as the use of genus name Rhizomonas van Bruggen did not follow the rules of bacterial nomenclature (Yabuuchi et al., 1999).

Cultural practices, such as crop rotation, cover cropping, reduced nitrogen fertilizers, drip irrigation, and improved soil drainage, may reduce corky root to a certain extent (Alvarez et al., 1992; Subbarao et al., 1997; van Bruggen and Brown, 1990; van Bruggen et al., 1990a). The incidence of corky root can also be reduced by soil fumigation (O'Brien and van Bruggen, 1990) and by using lettuce transplants instead of direct-seeding (van Bruggen and Rubatzky, 1992), but these practices may not be economically feasible (Patterson et al., 1986) and alternative strategies are needed.

The use of cultivars resistant to $S$. suberifaciens has been and should continue to be an important management strategy for corky root. Dickson (1963) screened 44 accessions of Lactuca sativa and identified three resistant accessions, including a line from Turkey,

Received for publication 20 Dec. 2003. Accepted for publication 9 Apr. 2004 We would like to thank Richard Michelmore, Murshidul Hoque, and Polly Goldman for their critical review and discussion of the manuscript. The technical assistance of JoAnn Tanaka and Polly Goldman is greatly appreciated. Mention of a trade name, proprietary product, or vendor does not constitute an endorsement, guarantee, or warranty by the U.S. Dept. of Agriculture (USDA) and does not imply its approval to the exclusion of other products or vendors that may be suitable. This research was supported in part by grants from the California Lettuce Research Board.

${ }^{1}$ Research Geneticist; to whom correspondence should be addressed. E-mail address: bmou@pw.ars.usda.gov

${ }^{2}$ Research Plant Pathologist.
PI 171669. Sequiera $(1970,1978)$ found five resistant lines from 172 accessions screened in the greenhouse, and released resistant cultivars Marquette, Montello, and Green Lake from crosses to PI 171669. Brown and Michelmore (1988) screened 555 accessions of Lactuca L. species in greenhouse for resistance to $S$. suberifaciens strain CA1 and identified 19 resistant accessions. Brown and Michelmore further demonstrated that the resistance was conferred by a recessive allele at a single locus (cor), which has been deployed in most resistant lettuce cultivars. The pathogen is diverse with respect to virulence, however, and several strains have been isolated that can cause certain disease symptoms on cultivars even though they have cor that to date is still the only known resistance gene (van Bruggen, 1997).

No universal source of resistance against all strains of the pathogen has been found, and monogenic resistance may not be durable as new virulent forms of the pathogen may arise. It is therefore desirable to find new sources of resistance to diversify the genetic basis of the resistance and to confer resistance to isolates that are not adequately controlled by cor. Prior to our research, more than half of the accessions in the U.S. Dept. of Agriculture (USDA) lettuce germplasm collection had not been screened for corky root resistance. The purposes of the present experiments were to screen lettuce germplasm for corky root resistance and to determine if greenhouse and/or growth chamber test results are correlated to results from field tests and can therefore be used to increase the volume of germplasm screened.

\section{Materials and Methods}

The experiments were conducted at the Agricultural Research Station of the USDA, Salinas, Calif., in 2001 and 2002. Genotypes not previously screened, including 811 plant introduction (PI) lines and 224 cultivars from the Salinas germplasm collection, were used in this study. They included crisphead, leaf, romaine, butterhead, stem, latin, batavia, and primitive forms of lettuce, and the wild species Lactuca serriola, L. saligna $\mathrm{L}$., and L. virosa from different geographic areas.

In a preliminary screening, 20 seeds of each genotype were planted in plastic pots $(10 \times 10 \times 10 \mathrm{~cm})$ containing a mixture of 
2 sand : 1 sterilized field soil (by volume) and were germinated in a greenhouse in June 2001. After emergence, seedlings were thinned to 10 plants per pot. To prepare inocula, mature taproots with corky root symptoms were collected from an infected lettuce field and washed with water. Each taproot was cut into small pieces and was blended for $20 \mathrm{~s}$ in a Waring blender (Waring Products, New Hartford, Conn.) half-full of water. The root suspension was filtered through a single layer of cheesecloth, and the extract was diluted with water to a total volume of $1.5 \mathrm{~L}$ per root. Plants were inoculated by pouring the suspension into pots of 3-week-old seedlings (with two to four leaves) at $150 \mathrm{~mL}$ per pot. Cultivars known to be either resistant ('Glacier', 'Green Lake', and 'Montello') or susceptible ('Salinas', 'White Boston', and 'Winter Density') were included as negative and positive controls, respectively. The roots of control plants were examined periodically to monitor disease progress. Disease severity for each plant was recorded using Brown and Michelmore's (1988) scale of $0-9$. Plants with a rating $<3$ were considered resistant, those with ratings of 3-6 were considered partially resistant and those with ratings of $>6$ were susceptible. As expected, the susceptible controls were all susceptible and all resistant controls were resistant to corky root.

From the preliminary screening, 81 putative resistant or partially resistant genotypes were identified. These lines, along with six resistant ('Glacier', 'Green Lake', 'Montello', PI 289064a, PI 491250, and PI 491251) and three susceptible ('Salinas', 'White Boston', and 'Winter Density') controls, were grown in vermiculite in cells $[3 \times 3 \times 5$-cm (length $\times$ width $\times$ depth) $]$ of a plastic tray. The plants were treated with a suspension of cells of Sphingomonas suberifaciens strain CA1 (van Bruggen etal., 1988) in S-broth according to previously published procedures (Brown and Michelmore, 1988). After inoculation, one set of plants was grown in growth chamber and another set of plants was grown in greenhouse. In each environment, plants were arranged in a randomized complete-block design with each genotype having eight replications and one plant per replication. The plants in the growth chamber were maintained at 12 -h photoperiod with 27 ${ }^{\circ} \mathrm{C}$ light $/ 15^{\circ} \mathrm{C}$ dark. Temperature in the greenhouse varied from 25 to $30{ }^{\circ} \mathrm{C}$ during the day. From the greenhouse and growth chamber tests, 23 resistant and partially resistant genotypes were identified. These lines plus five resistant ('Glacier', 'Green Lake', 'Montello', PI 491250, and PI 491251) and six susceptible ('Salinas', 'White Boston', 'Winter Density', PI 274901, PI 278091 a, and PI 491035) controls were planted in a field with a history of corky root disease in a randomized complete block with eight replications in Aug. 2002. Each plot consisted of 10 plants, with $30 \mathrm{~cm}$ between plants and $35 \mathrm{~cm}$ between rows on 1-m-wide double-row beds. Roots of each plant were examined at maturity, and because the disease incidence and severity was not uniform for all plants in a plot, the plant with the highest disease severity rating in each plot was used for analysis. Data were analyzed statistically by using the analysis of variance (ANOVA) and correlation functions of Microsoft Excel (Microsoft Office 2001; Microsoft Corp., Redmond, Wash.). Genotype means were used to calculate correlation coefficients of disease severity ratings in the growth chamber, greenhouse, and field.

Leaf samples of each genotype were collected from plants grown in the field experiment and DNA was isolated using the method of Dellaporta (1994). The DNA was analyzed by polymerase chain reaction (PCR) using primers for two flanking markers SCY15 and SC853 that are located 2.3 centimorgans (cM) from the cor gene as described by Moreno-Vazquez et al.
(2003). PCR mixes in $25-\mu \mathrm{L}$ volumes contained the following: $0.2 \mathrm{~mm}$ of each dNTP, $2.5 \mathrm{~mm} \mathrm{MgCl}_{2}, 0.5 \mu \mathrm{M}$ of each primer, $0.5 \mu \mathrm{g}$ genomic DNA, 0.5 unit Taq DNA polymerase (Promega, Madison, Wis.), and $1 \times$ polymerase buffer (Promega). Amplifications were performed in a PTC-200 thermocycler (MJ Research, Waltham, Mass.) starting with an initial denaturation for 3 min at $94{ }^{\circ} \mathrm{C}$, followed by 40 cycles of $1 \mathrm{~min}$ at $94^{\circ} \mathrm{C}, 1 \mathrm{~min}$ at $57^{\circ} \mathrm{C}$, and $1 \mathrm{~min}$ at $72{ }^{\circ} \mathrm{C}$ and finishing with 5 min extension at $72{ }^{\circ} \mathrm{C}$. Electrophoresis of PCR products was done in $2 \%$ agarose gels containing ethidium bromide in $1 \times$ TBE buffer.

\section{Results and Discussion}

This is the first report to evaluate the correlation between corky root disease severity in inoculated tests in controlled environments (growth chamber or greenhouse) and field tests. It is important to understand whether tests in controlled environments can be used to screen for corky root resistance, and if these results will hold up in further field testing. The results from growth chamber and greenhouse tests were highly correlated, and they had significant but lower correlation with the result from the field (Table 1). This suggests that controlled growth chamber or greenhouse tests inoculated with a single pathogen were effective for resistance screening, but resistances found still have to be verified in the field.

Although there were significant differences in corky root disease severity among the genotypes tested regardless of whether the plants were grown in the growth chamber, greenhouse, or field, location had a significant influence on disease severity (Table 2). Importantly, there was a significant genotype $\times$ location interaction. This suggests that the genotypes responded differently to the pathogen in different environments or that the environments differed with respect of the isolates of $S$. suberifaciens present or other important factors.

The purified strain used in the growth chamber and greenhouse experiments, strain CA1, is a pathotype of S. suberifaciens and has been used in many studies evaluating the ecology and control of corky root (O'Brien and van Bruggen, 1992a, 1992b, 1993; van Bruggen et al., 1988, 1990a). Additionally, this strain was used as the inoculum in a previous study screening germplasm for resistance in the greenhouse (Brown and Michelmore, 1988). Although this pathogen was originally isolated from corked roots of crisphead lettuce from a field in Salinas in 1984, it is not known if this strain is representative of the prevalent isolates in lettuce fields. This study suggests that using a single strain in controlled greenhouse or growth chamber experiments may not mimic the situation in the field. It has been suggested that in the field, there may be other strains of $S$. suberifaciens or similar species that can overcome the resistant gene cor (van Bruggen, 1997). However, the other strains or species seem not as virulent as CA1 and did not cause as high levels of disease as CA1 in inoculated tests in greenhouse (van Bruggen, 1994). This is consistent with our result that many accessions were resistant to CA1 in growth chamber and greenhouse tests but were only partially resistant when planted in the field (Table 3). Field experiment or field-collected inoculum (as used in our preliminary screening) prevents the selection of genotypes that are resistant to only the limited collection of lab strains. In earlier screening experiments (Dickson, 1963; Sequiera, 1970), lettuce seedlings were planted or transplanted into soil collected from affected fields. The resistance found was later confirmed and the resistant gene (cor) was identified, using strain CA1 (Brown and Michelmore, 
Table 1. Correlation coefficients $(n=34)$ for corky root $(C R)$ disease severity ratings of 34 lettuce accessions grown in the growth chamber, greenhouse, and field.

\begin{tabular}{lcc}
\hline Traits & $\begin{array}{c}\text { CR rating, } \\
\text { greenhouse }\end{array}$ & $\begin{array}{c}\text { CR rating, } \\
\text { field }\end{array}$ \\
\hline CR rating, growth chamber & $0.931^{* *}$ & $0.650^{* *}$ \\
CR rating, greenhouse & --- & $0.722^{* *}$ \\
\hline
\end{tabular}

**Significant at $P=0.01$ level.

Table 2. Mean squares of corky root disease severity from analysis of variance for 34 lettuce genotypes tested in three different locations (growth chamber, greenhouse, and field) each with eight replications.

\begin{tabular}{lrc}
\hline Source & df & Mean squares \\
\hline Replication & 21 & $6.57^{* *}$ \\
Location & 2 & $318.35^{* *}$ \\
Genotype & 33 & $98.61^{* *}$ \\
Genotype $\times$ location & 66 & $9.05^{* *}$ \\
Error & 693 & 1.92 \\
\hline
\end{tabular}

${ }^{* *}$ F tests significant at $P=0.01$ level.

1988). Therefore, it seems that cor is resistant to more virulent strains of the pathogen in the field. Even if a new resistant gene is identified, it still takes many years for breeders to incorporate the resistance into commercially accepted cultivars. Hence the continued use of the existing resistant gene cor is still important for the lettuce industry.

One problem with field tests in naturally infested soil is that the pathogen diversity and population levels may not be uniform and therefore some locations may not have high enough populations of aggressive strains to cause the disease. We currently do not have an understanding of the spatial and temporal population dynamics of naturally occurring $S$. suberifaciens strains that could help us to develop more uniform fields for evaluation of germplasm. Therefore, besides selecting a test field with a history of corky root disease, we used only the plant with the highest disease severity rating in a plot to calculate the mean severity for each genotype and used eight replications to minimize the problem.

Importantly, three L. serriola accessions (PI 491096, PI 491110, and PI 491239) and a L. virosa accession (PI 273597c) were consistently resistant to corky root in all three screening locations (Table 3 ) and were therefore considered to be highly resistant. An L. serriola line, PI 491094, was apparently resistant in the growth chamber and greenhouse tests, but was susceptible in the field. Four L. sativa genotypes (PI 491017, PI 491050, PI 509531, and Amaral 2000-97) and an L. saligna line (PI 509523) consistently showed partial resistance in all tests.

The resistant control 'Glacier' (Ryder and Waycott, 1994) was derived from a cross with another resistant genotype 'Green Lake' that has the resistant gene cor (Brown and Michelmore, 1988). 'Glacier' was resistant to corky root in growth chamber and greenhouse tests but was only partially resistant in the field, while 'Green Lake' remained resistant in all tests (Table 3). This suggests that besides the major gene cor, there may be other minor genes that might have gotten lost during the transfer from' Green Lake' to 'Glacier'. Those genes might be important in conditioning the resistance against other isolates in the field. Brown and Michelmore (1988) found that the resistance to corky root in 'Marquette' was less stable in different greenhouse tests although it has the same resistant allele as 'Green Lake', suggesting the presence of modifying genes.

Two molecular markers closely linked to the resistant gene cor, SCY15 and SC853 (Moreno-Vazquez et al., 2003), were
Table 3. Means and least significant differences $\left(\mathrm{LSD}_{0.05}\right)$ of corky root severity for 34 lettuce genotypes evaluated in growth chamber, greenhouse, and the field.

\begin{tabular}{llccc}
\hline & & \multicolumn{3}{c}{ Corky root severity $^{z}$} \\
\cline { 3 - 5 } Genotype & Species & $\begin{array}{c}\text { Growth } \\
\text { chamber }\end{array}$ & Greenhouse & Field \\
\hline PI 169509 & L. sativa & 2.0 & 3.1 & 4.8 \\
PI 261651b1 & L. sativa & 0.5 & 1.3 & 4.0 \\
PI 273577c & L. sativa & 1.4 & 1.4 & 5.0 \\
PI 273597c & L. virosa & 1.8 & 1.7 & 2.5 \\
PI 274901y & L. virosa & 7.9 & 7.9 & 7.3 \\
PI 278091ay & L. sativa & 8.0 & 8.0 & 8.0 \\
PI 289064a & L. sativa & 2.0 & 1.4 & 5.5 \\
PI 289065e & L. sativa & 3.3 & 4.4 & 7.8 \\
PI 491017 & L. sativa & 3.9 & 3.9 & 5.0 \\
PI 491035y & L. sativa & 7.6 & 7.4 & 7.8 \\
PI 491050 & L. sativa & 3.1 & 5.8 & 5.8 \\
PI 491088 & L. serriola & 1.3 & 1.9 & 5.4 \\
PI 491094 & L. serriola & 1.4 & 2.5 & 7.9 \\
PI 491096 & L. serriola & 1.4 & 1.4 & 2.4 \\
PI 491105 & L. serriola & 2.1 & 1.9 & 5.0 \\
PI 491107 & L. serriola & 1.9 & 1.8 & 5.6 \\
PI 491110 & L. serriola & 1.6 & 1.5 & 3.0 \\
PI 491239 & L. serriola & 1.1 & 1.1 & 2.3 \\
PI 491242 & L. serriola & 1.9 & 1.2 & 5.3 \\
PI 491250x & L. serriola & 1.5 & 1.8 & 4.9 \\
PI 491251x & L. serriola & 1.7 & 1.6 & 5.4 \\
PI 509523 & L. saligna & 3.7 & 2.8 & 3.6 \\
PI 509531 & L. sativa & 4.3 & 2.3 & 4.4 \\
\#10 & L. sativa & 4.6 & 5.4 & 6.9 \\
Amaral 2000-97 & L. sativa & 4.5 & 5.4 & 3.1 \\
Anthem & L. sativa & 4.8 & 5.6 & 6.2 \\
Artemis & L. sativa & 4.1 & 6.1 & 6.5 \\
Bistro & L. sativa & 4.3 & 6.3 & 7.8 \\
Glacierx & L. sativa & 1.8 & 1.8 & 5.1 \\
Green Lakex & L. sativa & 2.4 & 2.3 & 2.5 \\
Montellox & L. sativa & 1.3 & 1.3 & 3.0 \\
Salinasy & L. sativa & 7.6 & 7.5 & 8.1 \\
White Bostony & L. sativa & 7.2 & 6.9 & 7.3 \\
Winter Densityy & L. sativa & 7.2 & 7.7 & 7.8 \\
Mean & & 3.4 & 3.7 & 5.4 \\
LSD 0.05 & 1.3 & 1.1 & 1.7 \\
\hline 2Disease severity & was rated & B. & & \\
\hline
\end{tabular}

$\overline{{ }^{2} \text { Disease severity was rated using Brown and Michelmore's (1988) }}$ scale of $0-9$.

y Susceptible controls.

xResistant controls.

used to analyze the new resistant sources identified in this study (Fig. 1). Unlike the resistant control that has cor allele, the four highly resistant PI lines showed marker fragments linked to the susceptible allele Cor. This is in contrast to the result of MorenoVazquez et al. (2003) who reported that all 25 resistant cultivars and landraces examined had marker fragments linked to the resistant allele cor. It is common for susceptible germplasm to have the marker correlated with resistance, but the resistant materials having the marker correlated with susceptibility have been less frequently observed (Geffroy et al., 1998; Haley et al., 1993; Miklas et al., 1993, 2000). Despite repeated attempts, no DNA fragment could be amplified from the newly identified resistant line, PI 491239, with the SCY15 marker although the fragment was amplified from DNA of other genotypes and positive controls. One or more primer sequences for this marker may have been 
A.

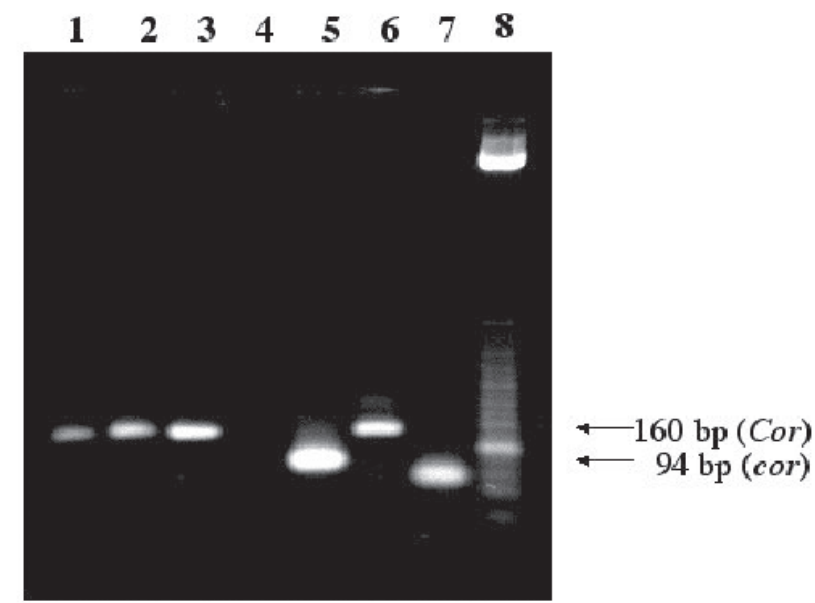

B.

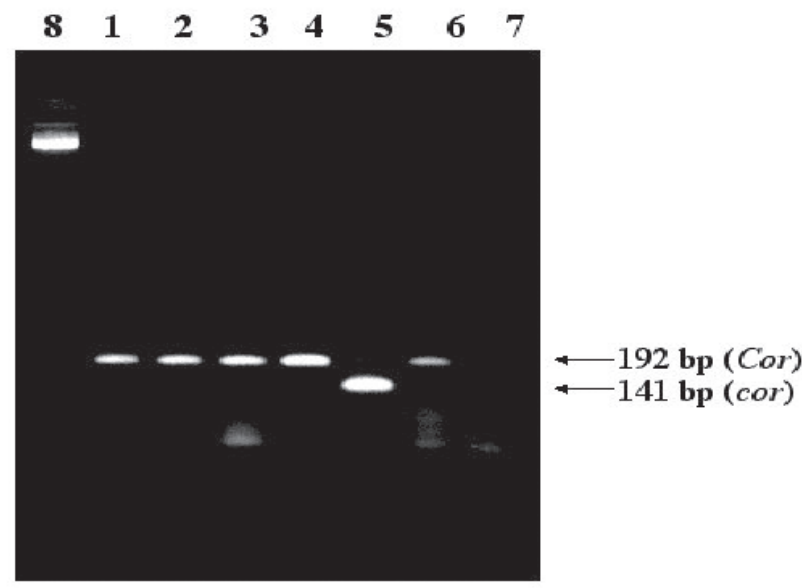

Fig. 1. Analysis of corky-root-resistant lettuce germplasm with molecular markers. 1, PI 273597c; 2, PI 491096; 3, PI 491110; 4, PI 491239; 5, 'Glacier' (resistant control); 6, 'White Boston' (susceptible control); 7, water control; 8, 25 basepair (bp) DNA Ladder (Life Technologies, Rockville, Md.). (A) PCR analysis with SCY15 SCAR marker. A 160-bp DNA fragment was associated with the susceptible allele Cor, and a 94-bp fragment was associated with the resistant allele cor. (B) PCR analysis with SC853 SCAR marker. A 192-bp DNA fragment was associated with the susceptible allele Cor, and a 141-bp fragment was associated with the resistant allele cor.

lost or changed in PI 491239 due to recombination, deletion, or mutation. Moreno-Vazquez et al. (2003) also found null alleles present for marker SCY15 in landraces PI 171675 and PI 171676. These results do not necessarily prove that the new resistant lines identified in this study do not possess the cor allele. Although these markers flank $(2.3 \mathrm{cM})$ the cor allele, recombination still can occur between these markers and the cor allele. The question of whether these genotypes have a new resistant gene has to be answered through allelism tests.
Resistant varieties remain the most economical means of controlling corky root disease. Now almost all accessions in the USDA lettuce germplasm collections have been screened for resistance to the disease. We have identified new resistant accessions in lettuce germplasm in this study. Lactuca serriola and $L$. sativa cross freely with each other, but the hybrids between $L$. virosa and $L$. sativa are sterile, and methods such as chromosome doubling (Thompson and Ryder, 1961) or in vitro rescue of immature embryos (Maisonneuve, 2003) must be used to produce progeny. Although the transfer of resistance from wild species often brings in horticulturally undesirable traits and may need additional backcrosses to eliminate these traits, wild species as sources of resistance can be used in a breeding program to broaden the genetic base of the resistance. This may diversify the selection pressure on the pathogen to overcome the only resistant gene, cor, presently employed, and increase the longevity of the resistance to corky root.

\section{Literature Cited}

Alvarez, J., L.E. Datnoff, and R.T. Nagata. 1992. Crop rotation minimizes losses from corky root in Florida lettuce. HortScience 27:66-68.

Brown, P.R. and R.W. Michelmore. 1988. The genetics of corky root resistance in lettuce. Phytopathology 78:1145-1150.

Dellaporta, S. 1994. Plant DNA miniprep and microprep: Versions 2.12.3, Method II, p. 524-525. In: M. Freeling and V. Walbot (eds.). The maize handbook. Springer-Verlag, New York.

Dickson, M.H. 1963. Resistance to corky root rot in head lettuce. J. Amer. Soc. Hort. Sci. 82:388-390.

Geffroy, V., F. Creusot, J. Falquet, M. Sevignac, A.F. Adam-Blondon, H. Bannerot, P. Gepts, and M. Dron. 1998. A family of LRR sequences in the vicinity of the $\mathrm{Co}-2$ locus for anthracnose resistance in Phaseolus vulgaris and its potential use in marker-assisted selection. Theor. Appl. Genet. 96:494-502.

Haley, S.D., P.N. Miklas, J.R.Stavely, J. Byrum, and J.D. Kelly. 1993. Identification of RAPD markers linked to a major rust resistance gene block in common bean. Theor. Appl. Genet. 86:505-512.

Maisonneuve, B. 2003. Lactuca virosa, a source of disease resistance genes for lettuce breeding: Results and difficulties for gene introgression, p. 61-67. In: T.J.L. van Hintum, A. Lebeda, D. Pink, and J.W. Schut (eds.). Eucarpia leafy vegetables 2003. Proc. of the Eucarpia meeting on leafy vegetables genetics and breeding, Noordwijkerhout, the Netherlands, 19-21 Mar. 2003. Centre for Genetic Resources, the Netherlands (CGN), Wageningen.

Miklas, P.N., L. Afanador, and J.D. Kelly. 1993. Identification and potential use of a molecular marker for rust resistance in common bean. Theor. Appl. Genet. 85:745-749.

Miklas, P.N., R.C. Larsen, R. Riley, and J.D. Kelly. 2000. Potential marker-assisted selection for bc-12 resistance to bean common mosaic potyvirus in common bean. Euphytica 116:211-219.

Moreno-Vazquez, S., O. Ochoa, N. Faber, S. Chao, J.M.E. Jacobs, B. Maisonneuve, R.V. Kesseli, and R.W. Michelmore. 2003. SNP-based codominant markers for a recessive gene conferring resistance to corky root rot (Rhizomonas suberifaciens) in lettuce (Lactuca sativa). Genome 46:1059-1069.

O'Brien, R.D. and A.H.C. van Bruggen. 1990. Soil fumigation with dazomet and methyl bromide for control of corky root of iceberg lettuce. Plant Dis. 74:1022-1025.

O’Brien, R.D. and A.H.C. van Bruggen. 1992a. Accuracy, precision, and correlation to yield loss of disease severity scales for corky root of lettuce. Phytopathology 82:91-96.

O'Brien, R.D. and A.H.C. van Bruggen. 1992b. Yield losses to iceberg lettuce due to corky root caused by Rhizomonas suberifaciens. Phytopathology 82:154-159.

O'Brien, R.D. and A.H.C. van Bruggen. 1993. Effect of temperature on corky root disease of lettuce and growth of the pathogen Rhizomonas suberifaciens. Can. J. Plant Pathol. 15:85-90. 
Patterson, C.L., R.G. Grogan, and R.N. Campbell. 1986. Economically important diseases of lettuce. Plant Dis. 70:982-987.

Ryder, E.J. and W. Waycott. 1994. Crisphead lettuce resistant to corky root: Cultivars Glacier and Misty Day and 16 resistant breeding lines. HortScience 29:335-336.

Sequiera, L. 1970. Resistance to corky root rot in lettuce. Plant Dis. Rep. 54:754-758.

Sequiera, L. 1978. Two root rot resistant varieties of head lettuce. Wisconsin Agr. Expt. Sta. Rpt. p. 2.

Subbarao, K.V., J.C. Hubbard, and K.F. Schulbach. 1997. Comparison of lettuce diseases and yield under subsurface drip and furrow irrigation. Phytopathology 87:877-883.

Thompson, R.C. and E.J. Ryder. 1961. Description and pedigree of nine varieties of lettuce. U.S. Dept. Agr. Tech. Bul. 1224.

van Bruggen, A.H.C. 1994. Etiology, epidemiology and control of lettuce corky root. Annual report of the California Iceberg Lettuce Advisory Board. p. 109-117.

van Bruggen, A.H.C. 1997. Corky root, p. 28-29. In: R.M. Davis, K.V. Subbarao, R.N. Raid, and E.A. Kurtz (eds.). Compendium of lettuce diseases. APS Press, St. Paul, Minn. van Bruggen, A.H.C. and P.R. Brown. 1990. Distinction between infectious and noninfectious corky root of lettuce in relation to nitrogen fertilizer. J. Amer. Soc. Hort. Sci. 115:762-770.

van Bruggen, A.H.C., P.R. Brown, C. Shennan, and A.S. Greathead. 1990a. The effect of cover crops and fertilization with ammonium nitrate on corky root of lettuce. Plant Dis. 74:584-589.

van Bruggen, A.H.C., K.N. Jochimsen, and P.R. Brown. 1990b. Rhizomonas suberifaciens gen. Nov., sp. Nov., the causal agent of corky root of lettuce. Intl. J. Syst. Bacteriol. 40:175-188.

van Bruggen, A.H.C., R.G. Grogan, C.P. Bogdanoff, and C.M. Waters. 1988. Corky root of lettuce in California caused by a gram-negative bacterium. Phytopathology 78:1139-1145.

van Bruggen, A.H.C. and V.E. Rubatzky. 1992. Use of transplants instead of direct seeding to reduce corky root severity and losses due to corky root in iceberg lettuce. Plant Dis. 76:703-708.

Yabuuchi, E., Kosako, Y., Naka, T., Suzuki, S., and Yano. 1999. Proposal of Sphingomonas suberifaciens (van Bruggen, Jochimsen, and Brown 1990) comb. Nov., Sphingomonas natatoria (Sly 1985) comb. Nov., Sphingomonas ursincola (Yurkov et al. 1997) comb. Nov., and emendation of the genus Sphingomonas. Microbiol. Immunol. 43:339-349. 